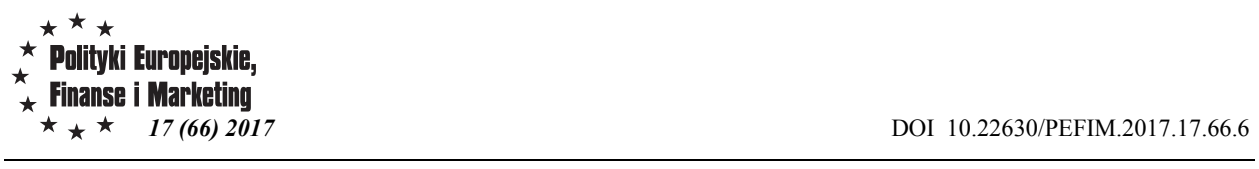

Berenika Karaszkiewicz

Iwona Staniec

Politechnika Lódzka

\title{
Testowanie występowania „efektu stycznia” na podstawie indeksu sWiG80
}

\section{TESTING THE OCCURRENCE OF THE "JANUARY EFFECT" BASED ON THE SWIG80 INDEX}

\begin{abstract}
Celem artykutu jest zbadanie, czy „efekt stycznia” determinuje notowania indeksu sWIG80 na Giełdzie Papierów Wartościowych w Warszawie. W badaniu wykorzystano miesięczne logarytmiczne stopy zwrotu indeksu sWIG80 za okres od stycznia 2007 do grudnia 2015 roku. Z badań wynika, że od roku 2007 „efekt stycznia” oddziatywat na stopy zwrotu z indeksu sWIG80 tylko jeden raz w roku $2012^{l}$. Przedstawione analizy moga być wykorzystywane $w$ podejmowaniu decyzji inwestycyjnych.
\end{abstract}

Słowa kluczowe: anomalie giełdowe, efekt stycznia, czynniki behawioralne

\section{Wprowadzenie}

Za najważniejszą teorię podważającą istotność racjonalności w finansach uważa się teorię perspektyw opracowaną przez Tversky'ego i Kahnemana ${ }^{2}$. Zakłada ona dążenie inwestora do maksymalizacji sumy użyteczności, przy czym uwzględnia również rozbieżności w ocenie poszczególnych wydarzeń przez uczestników rynku. Rozbieżności ich ocen wynikają z przyporządkowywania konkretnym obiektywnym wydarzeniom subiektywnych wag. Teoria perspektyw stała się podwaliną do rozwoju finansów behawioralnych. Według R. Olsena ${ }^{3}$ dalszym kierunkiem rozwijanym w finansach jest zrozumienie i przewidywanie systematycznych powikłań występujących na rynkach, a wynikających $\mathrm{z}$ psychologicznych aspektów podejmowania decyzji inwestycyjnych. Zatem finanse behawioralne są odpowiedzią na problemy występujące w klasycznej teorii finansów ${ }^{4}$.

\footnotetext{
1 W pracy magisterskiej B. Karaszkiewicz pt: Wpływ czynników behawioralnych na ceny rynkowych instrumentów finansowych napisanej pod kierunkiem dr inż. Iwony Staniec na Wydziale Organizacji i Zarządzania Politechniki Łódzkiej w 2016 roku przedstawiono szersze badania dotyczące anomalii sezonowych na GPW.

${ }^{2}$ D.Kahneman, A. Tversky Prospect Theory: An Analysis of Decision under Risk, Econometrica, XLVII (1979), 263-291.

${ }^{3}$ K.R. Olsen, Behavioral finance and it's implications for stock price volatility, "Financial Analysts Journal", 1998, Vol.54, No.2, s. 11.

${ }^{4}$ N. Barberis, R.H.Thaler, A survey of behavioral finance, Chapter 18 in Handbook of the Economics of Finance, vol. 1, Part 2, Elsevier Science, North Holland 2003, s. 1053, http://faculty.som.yale.edu/nicholasbarberis/ch18_6.pdf, 30.09.2016 r.
} 
Istnienie i oddziaływanie czynników behawioralnych przyczynia się do zmiany zapatrywań na możliwość uzyskiwania ponadprzeciętnych dochodów przez inwestorów. Burzy to uznawaną za kluczową w nauce finansów hipotezę o efektywności rynku kapitałowego według której stopień efektywności rynku decyduje o dostępności określonych informacji, które błyskawicznie są przetwarzane przez graczy i odzwierciedlane w cenach walorów, tym samym wykluczając możliwość uzyskania przez nich ponadprzeciętnych dochodów. Jednym z takich czynników jest „efekt stycznia". W prezentowanej pracy postawiono trzy pytania badawcze:

1. Czy „efekt stycznia” determinuje stopy zwrotu z indeksu sWIG80?

2. Czy w stopach zwrotu $\mathrm{z}$ indeksu sWIG80 ma zastosowanie barometr stycznia?

3. Czy występujące w badanym okresie zjawiska polityczno-ekonomicznospołeczne istotnie wpłynęly na stopy zwrotu z indeksu sWIG80?

\section{„Efekt stycznia"}

Teoria finansów behawioralnych dopuszcza możliwość zmian preferencji inwestorów i pojawiania się tzw. zachowań stadnych czyli wzajemnego podpatrywania i czerpania informacji z zachowań pozostałych uczestników rynku, odrzucając słuszność własnych źródeł wiedzy. Odstępstwa od hipotezy efektywnego rynku w literaturze określone zostały mianem anomalii rynkowych lub też giełdowych. Anomalia w odniesieniu do rynku kapitałowego to sytuacja umożliwiająca osiaganie dodatnich, ponadprzeciętnych stóp zwrotu ${ }^{5}$. Stąd, przewidywanie anomalii umożliwia zatem wygenerowanie zysku większego niż ten wynikający z relacji ryzyka i dochodu w tradycyjnym modelu wyceny aktywów rynku efektywnego nazywanym $\mathrm{CAPM}^{6}$.

Podstawowe anomalie giełdowe przedstawiane w literaturze to:

— anomalie sezonowe ${ }^{7}$ - zjawiska powtarzające się cyklicznie w określonych porach, np. rozkład miesięcznych stóp zwrotu, „efekt stycznia”, efekt dnia w tygodniu lub efekt weekendu, efekt przełomu miesiąca.

— anomalie fundamentalne ${ }^{8}$ - związane z charakterystyką spółki której dotyczą, ze szczególnym naciskiem na dane ekonomiczno - finansowe na temat tej spółki, np. efekt małych spółek (efekt kapitalizacji), zależność zmian stóp zwrotu i wskaźnika ceny do zysku, efekt ceny do wartości księgowej,

- anomalie związane z nadreaktywnością i subreaktywnością rynku' - zjawiska wynikające $\mathrm{z}$ odchylania się stóp procentowych od poziomu efektywnego, który odzwierciedla wszystkie informacje na temat spółek działających na rynku.

\footnotetext{
${ }^{5}$ M. Czerwonka, B. Gorlewski, Finanse behawioralne, Szkoła Główna Handlowa, Warszawa 2008, s.152. cyt. za: Peters E.E., Teoria chaosu, a rynki kapitałowe, WIG PRESS, Warszawa 1997, s. 36.

${ }^{6} \mathrm{~K}$. Jajuga, T. Jajuga, Inwestycje - instrumenty finansowe, ryzyko finansowe, inżynieria finansowa, Wyd. Naukowe PWN, Warszawa 1997, s. 167-170.

${ }^{7}$ Przedstawione sa one w pracach: E. Fama, „Efficient Capital Markets II”, Journal of Finance, No. 5. December 1991 oraz P. Fiszeder, J.Kożuchowska, Testowanie występowania wybranych anomalii kalendarzowych na GPW w Warszawie, w: A. Barczak, P. Tworek (red.), Zastosowanie metod ilościowych w zarzqdzaniu ryzykiem $w$ działalności inwestycyjnej, Wydawnictwo Uniwersytetu Ekonomicznego, Katowice 2013, s. 3, file:///C:/Users/user/Downloads/FiszederKo-uchowska.pdf, 30.06.2016 r.

${ }^{8}$ M. Czerwonka, B. Gorlewski Finanse behawioralne, Szkoła Główna Handlowa, Warszawa 2008, s. 157-159.

${ }^{9}$ M. Czerwonka, B. Gorlewski Finanse behawioralne, Szkoła Główna Handlowa, Warszawa 2008, s. 160-161.
} 
Za „efekt stycznia”"10 uważa się szczególny przypadek anomalii w rozkładzie miesięcznych stóp zwrotu. Zauważono, że podczas jego występowania w styczniu odnotowywane są dodatnie i najwyższe stopy zwrotu w porównaniu do pozostałych miesięcy. W literaturze podaje się dwie główne przyczyny występowania „efektu stycznia". Po pierwsze wynika on ze zmian cen akcji spółek, gdyż dochodzi do masowego wyprzedawania przez inwestorów na koniec roku tych akcji, które straciły w ostatnim okresie na wartości, gdyż to pozwala im na odliczenie zrealizowanej straty od podatku. Wzmożona sprzedaż powoduje zmniejszenie cen tychże papierów wartościowych znacznie poniżej ich wartości rzeczywistej. W efekcie w styczniu na rynku dostępne są niedowartościowane akcje, które szybko znajdują nowych nabywców. Badania pokazuja, że tzw. presja podażowa i sam „efekt stycznia” dotyczą akcji mniejszych spółek, które są bardziej podatne na wahania. Po drugie, przyczyną powstawania „efektu stycznia” jest wynagrodzenie osób zarząadzających portfelami. Wysokość wynagrodzenia menedżera uzależniona jest od wysokości jego wyników inwestycyjnych, dlatego na koniec roku dokonywane są rekonstrukcje portfeli polegające na wyprzedawaniu wszystkich akcji przynoszących straty w taki sposób, aby uzyskali oni możliwie najwyższą prowizję. W styczniu portfele klientów są odbudowywane i rozszerzane o bardziej ryzykowne papiery. Dodatkowo mówi się o występowaniu barometru stycznia ${ }^{11}$, czyli prognozie nadchodzącego roku tzn. znak indeksu giełdowego w styczniu decyduje o zysku lub stracie w danym roku. Zatem jeśli w styczniu indeksy będą miały znak dodatni, wówczas przez resztę roku wystapi trend wzrostowy, natomiast ujemny znak przy indeksach w pierwszym miesiącu zwiastuje spadki giełdowe aż do grudnia.

Teoria identyfikuje wiele różnorakich odchyleń od standardowych założeń hipotezy efektywnego rynku, które pozwalają generować ponadprzeciętne dochody. Badania przeprowadzane $\mathrm{w}$ wielu krajach na przestrzeni wielu lat potwierdzaja, że skala i rodzaj anomalii dla poszczególnych rejonów świata są zróżnicowane. Badania przedstawione w pracy M. Czerwonka i B. Godlewski dla lat $1997-2006$ pokazują że na Warszawskiej GPW dominującą anomalią jest „efekt stycznia”"12 gdyż najwyższe miesięczne średnie stopy zwrotu na poziomie ok. 5,27\% odnotowywano właśnie w styczniu. W badaniach pokazano, że stopy na podobnym poziomie kształtują się również w grudniu (5,15\%) co potwierdza tezę, że ,efekt stycznia” zapoczątkowywany jest już w roku poprzedzającym. Badania te również potwierdzają występowanie barometru stycznia $\mathrm{W}$ ośmiu na 12 badanych lat. W przedstawionych poniżej badaniach empirycznych uwzględniono kolejne lata tj. okres 2007 -2015.

\section{Metodologia badań}

Badanie zostało przeprowadzone na podstawie archiwalnych notowań indeksu sWIG80 w okresie od stycznia 2007 do grudnia 2015. Wszystkie dane pochodzą z serwisów: www.gpwinfostrefa.pl, www.stooq.pl. Indeks sWIG80 jest obliczany na podstawie

\footnotetext{
${ }^{10}$ A. Szyszka, Efektywność rynku kapitałowego, a anomalie w rozkładzie stóp zwrotu w czasie, „Nasz Rynek Kapitałowy" 1999, nr 12, s. 2-5, http://atinvest.pl/pdf/Efektywnoscrynkukapitalowego.pdf, 30.06.2016 r.

${ }_{11}$ M. Czerwonka, B. Gorlewski Finanse behawioralne, Szkoła Główna Handlowa Oficyna Wydawnicza, Warszawa 2008, s. 175.

${ }^{12}$ M. Czerwonka, B. Gorlewski Finanse behawioralne, Szkoła Główna Handlowa, Warszawa 2008, s. 171.
} 
notowań najmniejszych spółek GPW. Do przeprowadzenia badania obliczone zostały średnie miesięczne stopy zwrotu spółek wchodzących w skład wybranych indeksów za okres od stycznia 2007 do grudnia 2015 roku. Obliczenia przeprowadzono na podstawie dziennych notowań wybranych indeksów. W przypadku szacowania średnich miesięcznych stóp zwrotu zdecydowano się logarytmiczną stopę zwrotu. Wprawdzie daje ona niższe wartości niż zwykła stopa zwrotu, ale nie jest wrażliwa na wahania kursowe dzięki czemu wartości skrajne nie zawyżają ani nie zaniżają sztucznie jej wartości. Obliczono ją z wzoru:

$$
R_{t}=\ln \left(\frac{P_{t}}{P_{t-1}}\right) .
$$

Dane do badań ze względu na przejrzystość podzielono na trzy okresy trzyletnie:

$$
\begin{array}{ll}
\checkmark & \text { okres } 1 \text { - styczeń 2007 - grudzień 2009; } \\
\checkmark & \text { okres 2 - styczeń 2010 - grudzień 2012; } \\
\checkmark & \text { okres 3 - styczeń 2013 - grudzień 2015. }
\end{array}
$$

\section{Wyniki badań}

W styczniu 2007 logarytmiczna stopa zwrotu z indeksu sWIG80 przyjmowała wartość $12,73 \%$ (porównaj rys. 1). Była to druga pod względem wysokości zaraz po marcu $(17,31 \%$, która stanowi maksimum dla tego miesiąca) stopa zwrotu w ciagu roku. W okresie załamania giełdy na skutek światowego kryzysu (07.2007 - 02.2009) stopy zwrotu indeksu mniejszych spółek przyjmowały głównie wartości ujemne. Na podstawie opracowanej statystyki dla roku 2008 z wyjątkiem lutego we wszystkich pozostałych miesiącach logarytmiczna stopa zwrotu sWIG80 nie przekraczała zera. Odnotowano wówczas również aż siedem wartość minimalnych logarytmicznych stóp zwrotu oszacowanych dla poszczególnych miesięcy badanego okresu (-11,41\% w styczniu 2008 roku, $-8,47 \%$ w lutym 2009 roku, $-5,84 \%$ w kwietniu 2008 roku, $-12,46 \%$ w czerwcu 2008 roku, $-9,54 \%$ w lipcu 2008 roku, rekordowo $-25,77 \%$ w październiku 2008 roku oraz $-13,75 \%$ w listopadzie 2007 roku). Widać zatem, że gigantyczne straty giełdowe w październiku 2008 dotknęły także spółki mniejsze. W styczniu 2009 roku stopa wyniosła - 3,31\%, zatem nadal o „efekcie stycznia” nie mogło być mowy. Na skutek walki z kryzysem od marca 2009 sWIG80 odnotowywał zyski, maksymalna wartość stopy zwrotu z indeksu wystapiła w kwietniu 2009 roku na poziomie 20,98\%. W pierwszych miesiącach różnica między miesięcznymi stopami wynosiła nawet do kilku punktów procentowych, jednak do końca roku praktycznie zanikła (wartość stopy oscylowała w granicach zera). 


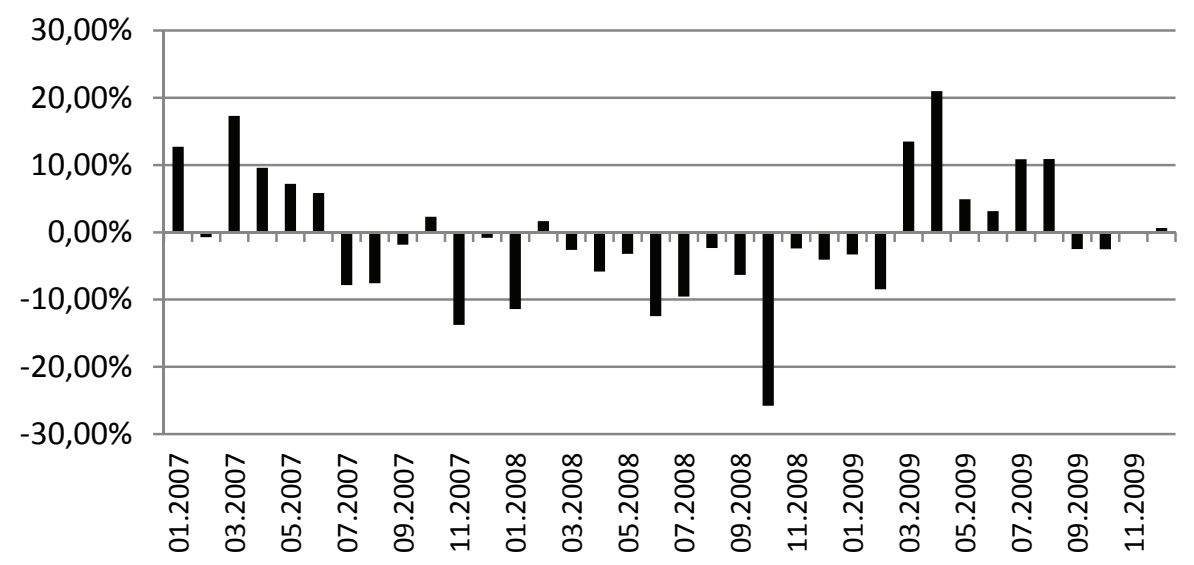

Rysunek 1. Średnie miesięczne logarytmiczne stopy zwrotu indeksu sWIG80 w latach 2007 - 2009 Źródto: Opracowanie własne

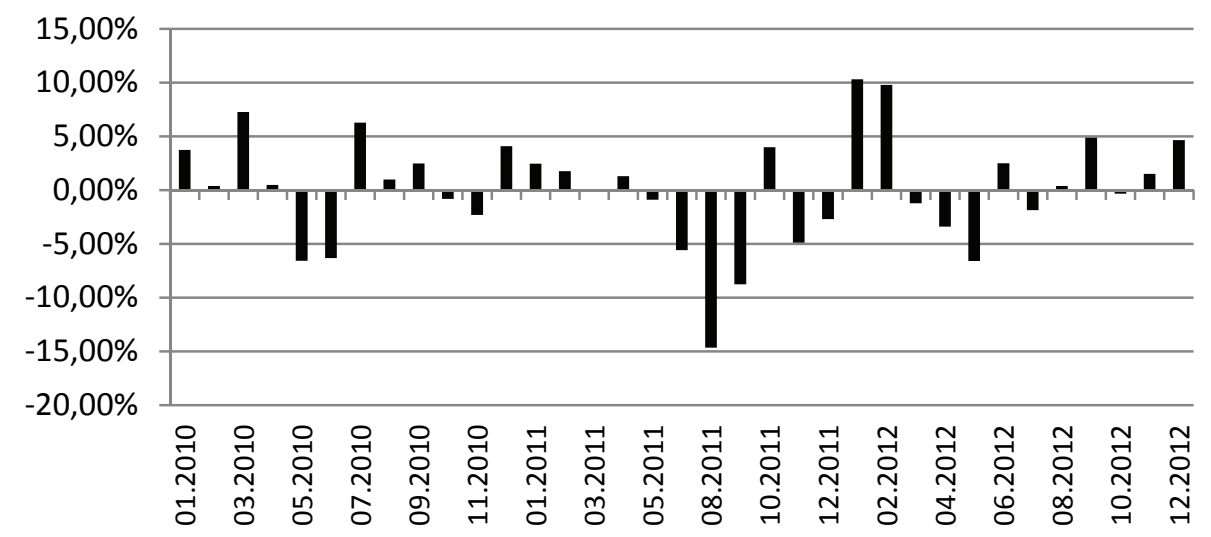

Rysunek 2. Średnie miesięczne logarytmiczne stopy zwrotu indeksu sWIG80 w latach 2010 - 2012 Źródlo: Opracowanie własne

W latach 2010 - 2011 w styczniu nie odnotowano najwyższych wartości stóp zwrotu w roku, jednakże dwukrotnie były one dodatnie (3,74\% i 2,47\% - patrz rys. 2). Wyraźnie widoczna jest tu reakcja na kryzys grecki. Stopa zwrotu z indeksu przyjęła w sierpniu i wrześniu 2011 roku minimalne wartości oszacowane dla poszczególnych miesięcy okresu badawczego (kolejno -14,65\% i -8,77\%). Styczeń roku 2012 okazał się najbardziej obiecujący w przypadku stopy zwrotu z indeksu sWIG80. Odnotowany wynik osiagnął $10,32 \%$ i tym samym potwierdziło się zaistnienie „efektu stycznia” w tym okresie. Warty uwagi jest fakt, iż w lutym tego roku wystappił ogromny dysonans pomiędzy notowaniami stop zwrotu dla WIG20 i sWIG80. Stopa zwrotu dużych spółek osiagnnęła wartość $-0,65 \%$, podczas gdy małe spółki utrzymały wysoki wzrost wartości na poziomie $9,78 \%$. W grudniu roku poprzedzającego 2011 stopa zwrotu była ujemna na poziomie $-2,69 \%$. 
Od roku 2013 do 2015 stopy zwrotu z notowań styczniowych były dodatnie, jednakże nie najwyższe w porównaniu do pozostałych miesięcy w roku (kolejno 7,40\%, $0,36 \%$ i 3,26\%-porównaj rys. 3). Jeśli chodzi o poziom stóp zwrotu w badanym podokresie - w odpowiedzi na reformę OFE oraz konflikty w Syrii i na Ukrainie sWIG80 w przeważającej liczbie miesięcy plasował się poniżej zera. Początek roku 2015 okazał się sprzyjający dla małych spółek (nastąpił wzrost o około 3,26 pkt \%), natomiast do jego zakończenia notowania stóp zwrotu zbliżały się w okolice zera. Odpowiedź na październikowe wybory była w przypadku tego indeksu optymistyczna- na giełdzie pojawił się wzrost stopy zwrotu do dodatniej wartości 3,15\%.

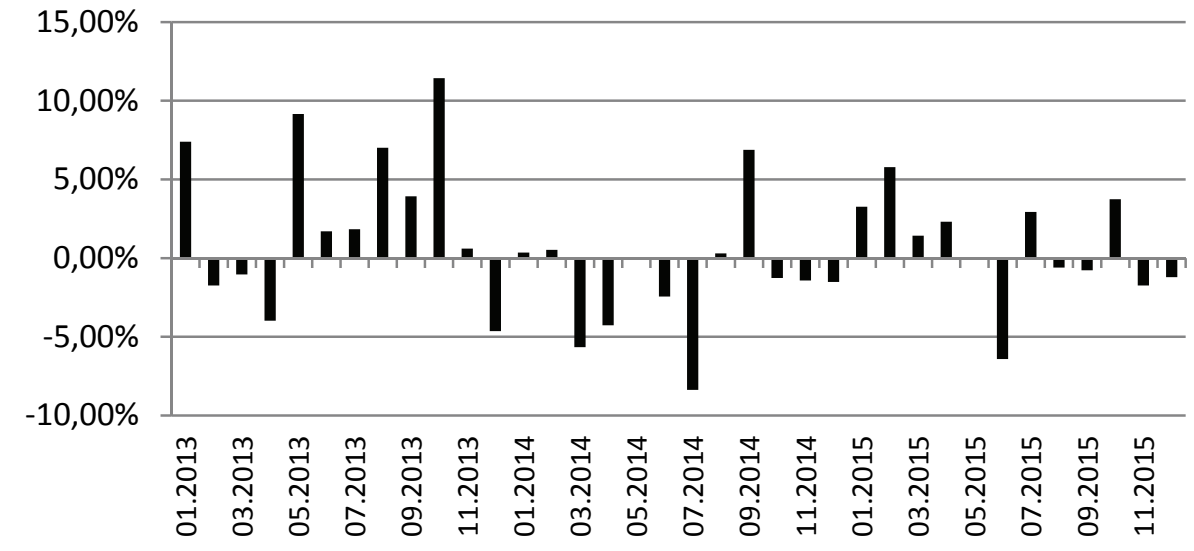

Rysunek 3. Średnie miesięczne logarytmiczne stopy zwrotu indeksu sWIG80 w latach 2013 - 2015 Źródto: Opracowanie własne

Podsumowując miesięczna logarytmiczna stopa zwrotu dla indeksu sWIG80 nie potwierdza występowania ,efektu stycznia”. Dodatnia stopa zwrotu wystapiła w styczniu 7 razy na 9 badanych lat, ale tylko raz w roku 2012 była to najwyższa wartość dla stycznia $(10,32 \%)$ w porównaniu do pozostałych miesięcy badanego roku (patrz tabela 1). Biorąc pod uwagę liczbę lat, w których stopa zwrotu indeksu dla danego miesiąca była dodatnia to właśnie styczeń okazał się liderem (aż 7 na 9), a kolejne miesiące roku wykazują tendencje spadkowe w tym zakresie. Poza latami kryzysu tj. 2008-2009 w całym okresie badawczym stopa zwrotu z indeksu sWIG80 na początku roku przekraczała wartość zero. 


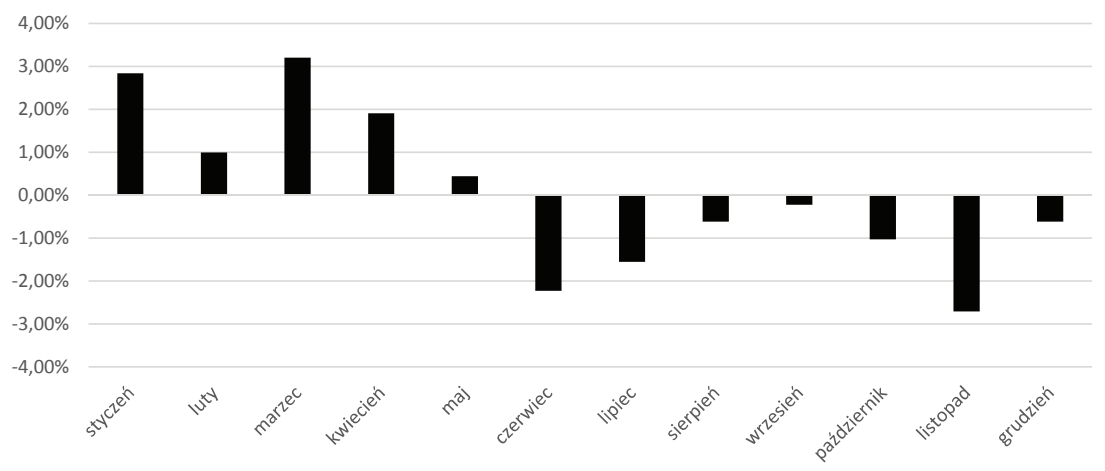

Rysunek 4. Średnie logarytmiczne miesięczne stopy zwrotu z indeksu sWIG80 w latach 2007-2015 Źródło: Opracowanie własne

Nie udało się powtórzyć wyniku uzyskanego w badaniach przedstawionych w pracy M. Czerwonka i B. Godlewski dla lat 1997 - 2006, gdyż największa wartość przeciętnej logarytmicznej stopy zwrotu dla indeksu sWIG80 występuje w miesiącu marcu $(3,20 \%)$, a styczeń jest dopiero na 2 pozycji z wartością $2,84 \%$. W grudniu roku poprzedzającego średnia jest znacznie niższa niż w styczniu roku następnego - stopy te są na różnych poziomach - zatem nie ma też rozpoczęcia „efektu stycznia” w roku poprzednim co było podkreślane w prezentowanych badaniach.

$\mathrm{Na}$ podstawie rys. 4 można zaobserwować także, że pierwsza połowa roku okazała się znacznie bardziej sprzyjającą inwestowaniu. Do maja wszystkie średnie wartości miesięcznych stóp zwrotu były dodatnie, co wskazywało na generalny wzrost majątków spółek w tym okresie. Z kolei od czerwca aż do końca roku na stałe zmienił się znak średniej wartości stopy zwrotu z indeksu, zatem statystycznie dobra passa dla inwestorów minęła. Najmniej sprzyjającym miesiącem okazał się listopad osiagając wartość średnią stopy zwrotu na poziomie -2,58\% (aż sześć na dziewięć możliwych miesięcy o spadkowym kursie w listopadzie).

Tabela1. Średnie miesięczne stopy zwrotu indeksu sWIG80 w latach $2007-2015$

Tabela1. Srednie miesięczne stopy zwrotu indeksu sWIG 80 w latach $2007-2015$
\begin{tabular}{|c|c|c|c|c|c|c|c|c|c|}
\hline & $\mathbf{2 0 0 7}$ & $\mathbf{2 0 0 8}$ & $\mathbf{2 0 0 9}$ & $\mathbf{2 0 1 0}$ & $\mathbf{2 0 1 1}$ & $\mathbf{2 0 1 2}$ & $\mathbf{2 0 1 3}$ & $\mathbf{2 0 1 4}$ & $\mathbf{2 0 1 5}$ \\
\hline styczeń & $12,73 \%$ & $-11,41 \%$ & $-3,31 \%$ & $3,74 \%$ & $2,47 \%$ & $10,32 \%$ & $7,40 \%$ & $0,36 \%$ & $3,26 \%$ \\
\hline luty & $-0,73 \%$ & $1,65 \%$ & $-8,47 \%$ & $0,39 \%$ & $1,76 \%$ & $9,78 \%$ & $-1,74 \%$ & $0,53 \%$ & $5,78 \%$ \\
\hline marzec & $17,31 \%$ & $-2,60 \%$ & $13,50 \%$ & $7,26 \%$ & $-0,15 \%$ & $-1,22 \%$ & $-1,03 \%$ & $-5,65 \%$ & $1,43 \%$ \\
\hline kwiecień & $9,60 \%$ & $-5,84 \%$ & $20,98 \%$ & $0,48 \%$ & $1,29 \%$ & $-3,40 \%$ & $-3,98 \%$ & $-4,27 \%$ & $2,31 \%$ \\
\hline maj & $7,20 \%$ & $-3,19 \%$ & $4,90 \%$ & $-6,57 \%$ & $-0,89 \%$ & $-6,60 \%$ & $9,15 \%$ & $-0,02 \%$ & $-0,01 \%$ \\
\hline czerwiec & $5,85 \%$ & $-12,46 \%$ & $3,14 \%$ & $-6,31 \%$ & $-5,58 \%$ & $2,49 \%$ & $1,70 \%$ & $-2,45 \%$ & $-6,42 \%$ \\
\hline lipiec & $-7,86 \%$ & $-9,54 \%$ & $10,86 \%$ & $6,28 \%$ & $-8,24 \%$ & $-1,86 \%$ & $1,84 \%$ & $-8,37 \%$ & $2,94 \%$ \\
\hline sierpień & $-7,56 \%$ & $-2,32 \%$ & $10,89 \%$ & $0,99 \%$ & $-14,65 \%$ & $0,39 \%$ & $7,01 \%$ & $0,30 \%$ & $-0,59 \%$ \\
\hline wrzesień & $-1,83 \%$ & $-6,31 \%$ & $-2,49 \%$ & $2,47 \%$ & $-8,77 \%$ & $4,89 \%$ & $3,93 \%$ & $6,89 \%$ & $-0,78 \%$ \\
\hline październik & $2,31 \%$ & $-25,77 \%$ & $-2,53 \%$ & $-0,82 \%$ & $4,00 \%$ & $-0,33 \%$ & $11,44 \%$ & $-1,27 \%$ & $3,75 \%$ \\
\hline listopad & $-13,75 \%$ & $-2,40 \%$ & $0,03 \%$ & $-2,30 \%$ & $-4,89 \%$ & $1,52 \%$ & $0,60 \%$ & $-1,42 \%$ & $-1,73 \%$ \\
\hline grudzień & $-0,81 \%$ & $-4,08 \%$ & $0,65 \%$ & $4,08 \%$ & $-2,69 \%$ & $4,65 \%$ & $-4,64 \%$ & $-1,52 \%$ & $-1,20 \%$ \\
\hline
\end{tabular}


Przedstawienie $\mathrm{w}$ tabeli 1 logarytmicznych stóp zwrotu w kolejnych latach $\mathrm{z}$ podziałem na konkretne miesiące wskazuje, iż najmniejszymi wahaniami stóp zwrotu charakteryzują się maj, wrzesień, listopad i grudzień (wartości z kilkoma wyjątkami oscylujące w granicach $+/-5$ pkt \%). Środek oraz koniec roku jest więc dobrym czasem na dokonywanie inwestycji w spółki mniejsze. Najbardziej efektywne inwestycyjnie miesiące to: marzec, kwiecień (możliwy do osiągnięcia zysk na poziomie $20 \%$, zaś strata nieprzekraczająca 5\%).

Niestety w badanych 9-ciu latach barometr stycznia nie wystąpił nawet raz, tzn. znak stopy zwroty w styczniu nie prognozował wzrostów lub spadków w pozostałych miesiącach. Warto ponadto zauważyć, że w grudniu roku poprzedniego stopy zwrotu są niższe niż styczniu - wyjątek stanowi grudzień 2007 i styczeń 2008 oraz grudzień roku 2010 i styczeń 2011.

Tabela 2. Analiza dwuczynnikowa wariancji bez powtórzeń dla średnich miesięcznych stóp zwrotu indeksu sWIG80 w latach $2007-2015$

\begin{tabular}{|l|c|r|r|r|r|r|}
\hline Źródło wariancji & \multicolumn{1}{c|}{ SS } & \multicolumn{1}{c|}{ df } & \multicolumn{1}{c|}{ MS } & \multicolumn{1}{c|}{ F } & Wartość-p & \multicolumn{1}{c|}{ Test F } \\
\hline miesiące & 0,035714 & 11 & 0,003247 & 0,859268 & 0,582467 & 1,899171 \\
\hline lata & 0,109412 & 8 & 0,013676 & 3,61953 & $\mathbf{0 , 0 0 1 1 1 1}$ & 2,045414 \\
\hline Błąd & 0,332509 & 88 & 0,003779 & & & \\
\hline & & & & & & \\
\hline Razem & 0,477635 & 107 & & & & \\
\hline
\end{tabular}

Podobieństwo pomiędzy stopami zwrotu dla indeksu sWIG80 przejawia się w powtarzalności notowań spadkowych lub wzrostowych w poszczególnych miesiącach, natomiast różnica występuje w odniesieniu do lat. Potwierdza to przeprowadzona analiza wariancji (tabela 2), która wykazała występowanie istotnej statystycznie różnicy $(\mathrm{p}<0,01)$ pomiędzy stopami zwrotu indeksu sWIG80 dla poszczególnych lat.

Tabela 3. Współczynnik korelacji stycznia i pozostałych miesięcy sWIG80 w latach 2007 - 2015

\begin{tabular}{|c|c|c|c|c|c|c|c|c|c|c|c|}
\hline miesiąc & $\mathbf{0 2}$ & $\mathbf{0 3}$ & $\mathbf{0 4}$ & $\mathbf{0 5}$ & $\mathbf{0 6}$ & $\mathbf{0 7}$ & $\mathbf{0 8}$ & $\mathbf{0 9}$ & $\mathbf{1 0}$ & $\mathbf{1 1}$ & $\mathbf{1 2}$ \\
\hline sWIG80 & 0,299 & 0,293 & 0,034 & 0,223 & $\mathbf{0 , 7 0 2}$ & 0,039 & $-0,158$ & 0,426 & $\mathbf{0 , 7 7 3}^{* *}$ & $-0,323$ & 0,357 \\
\hline $\mathbf{p}$ & 0,217 & 0,222 & 0,465 & 0,282 & $\mathbf{0 , 0 1 8}$ & 0,461 & 0,342 & 0,126 & $\mathbf{0 , 0 0 7}$ & 0,199 & 0,173 \\
\hline
\end{tabular}

Korelacja jest istotna jednostronnie *na poziomie $0,05 * *$ na poziomie 0,0 Źródło: Opracowanie własne

Z tabeli 3 widać, że nie występuje istotny statystycznie wpływ stopy zwroty w styczniu na pozostałe miesiące poza czerwcem i październikiem, kiedy to dodatnia stopa zwrotu indeksu sWIG80 sugeruje przeciętny wzrost stopy zwrotu w tych miesiącach. To też potwierdza brak występowania barometru stycznia w badanym okresie. 


\section{Wnioski}

Przeprowadzone analizy pozwoliły odpowiedzieć na postawione pytania badawcze. Po pierwsze „efekt stycznia” na giełdzie w przypadku indeksu sWIG80 w ostatnich latach praktycznie nie występuje. Wyjątek stanowi rok 2012, kiedy to rzeczony efekt rzeczywiście wystąpił. Obliczone w okresie 2007-2015 przeciętne logarytmiczne stopy zwrotu nie były najwyższe, jednakże styczeń osiaggnął drugą pod względem wysokości wartość średnią na poziomie $3,12 \%$. Wyższą notę uzyskał tylko marzec $\mathrm{z}$ wynikiem $3,54 \%$. Ponadto, poza latami kryzysu tj. 2008-2009 w całym okresie badawczym stopa zwrotu z indeksu sWIG80 na początku roku przyjmowała znak dodatni. W odniesieniu do małych spółek, można zaobserwować wyraźny podział roku na dwa okresy. Pierwszy, od stycznia do maja charakteryzował się dodatnimi średnimi wartościami miesięcznych stóp zwrotu, zaś od czerwca do grudnia - ujemnymi. Najniższy wynik przypadł na listopad ze średnia $-2,58 \%$. Najmniejsze wahania kursowe charakteryzują maj, wrzesień, listopad i grudzień (wartości oscylujące w granicach $+/-5$ pkt. \%). Po drugie w żadnym badanym roku nie odnotowano barometru stycznia. Po trzecie w stopach zwrotu widoczne są wydarzenia polityczne i gospodarcze tj.: kryzys finansowy i grecki, wybory parlamentarne, reforma OFE oraz konflikty w Syrii i na Ukrainie. Ich oddziaływanie nie wpłynęło jednak znacząco na notowania spółek sWIG80, ze względu na ich dużą odporność na tego typu bodźce. Jest to związane z większą liczbą spółek wchodzących w skład indeksu i co za tym idzie ich zdecydowanie mniejszymi udziałami (przeciętnie udział pojedynczej spółki jest na poziomie 1,25\%). Dzięki takiej strukturze sWIG80, wahania notowań pojedynczej spółki nie są w stanie znacząco wpłynąć na stopę zwrotu całego indeksu. Dodatkowo wśród przyczyn mniejszej podatności stóp zwrotu z indeksu sWIG80 na wydarzenia zewnętrzne znajduje się przede wszystkim fakt skupienia w nim mniejszych spółek akcyjnych w większym stopniu prowadzących swą działalność na rynku krajowym aniżeli duże spółki, które mogą być bardziej „wrażliwe” na wydarzenia międzynarodowe ze względu na większą ekspozycję na rynki zewnętrzne. Są to ważne informacje dla graczy, których interesuje długookresowe inwestowanie bez konieczności ponoszenia dużych nakładów finansowych. Dzięki swojej stabilności, mniejsze spółki zapewniają mniejsze ryzyko inwestycyjne na przyszłość.

Decydując się na zakup akcji małych spółek inwestor powinien rozważyć rozpoczęcie inwestycji w drugiej połowie roku, zaś sprzedaż wskazana jest na jego początek. Można wówczas sporo zyskać na różnicy pomiędzy ceną zakupu a wysokim kursem przy sprzedaży.

\section{Bibliografia}

Barberis N., Thaler R.H., A survey of behavioral finance, Chapter 18 in Handbook of the Economics of Finance, vol. 1, Part 2, Elsevier Science, North Holland 2003, http://faculty.som.yale.edu/nicholasbarberis/ch18 6.pdf, 30.09.2016.

Czerwonka M., Gorlewski B., Finanse behawiorāne, Szkoła Główna Handlowa, Warszawa 2008. Fama E., Efficient Capital Markets II, Journal of Finance, No. 5., December 1991.

Fiszeder P., Kożuchowska J., Testowanie występowania wybranych anomalii kalendarzowych na GPW w Warszawie, w: A. Barczak, P. Tworek (red.), Zastosowanie metod ilościowych $w$ zarzadzaniu ryzykiem $w$ działalności inwestycyjnej, Wydawnictwo Uniwersytetu Ekonomicznego, Katowice 2013, file://C:/Users/user/Downloads/FiszederKo-uchowska.pdf, 30.06.2016.

Jajuga K., Jajuga T., Inwestycje - instrumenty finansowe, ryzyko finansowe, inżynieria finansowa, Wyd. Naukowe PWN, Warszawa 1997. 
Kahneman D., Tversky A. Prospect Theory: An Analysis of Decision under Risk, Econometrica, XLVII (1979),s. 263-291.

Karaszkiewicz B. Wplyw czynników behawioralnych na ceny rynkowych instrumentów finansowych praca magisterska napisana pod kierunkiem dr inż. Iwony Staniec na Wydziale Organizacji i Zarządzania Politechniki Łódzkiej w 2016 roku.

Olsen K.R., Behavioral finance and it's implications for stock price volatility, "Financial Analysts Journal", 1998, Vol.54, No.2.

Peters E.E., Teoria chaosu, a rynki kapitałowe, WIG PRESS, Warszawa 1997

Szyszka A., Efektywność rynku kapitałowego, a anomalie w rozkładzie stóp zwrotu w czasie, „Nasz Rynek

Kapitałowy" 1999, nr 12, http://atinvest.pl/pdf/Efektywnoscrynkukapitalowego.pdf, 30.06.2016 r.

\section{Summary}

The aim of the study is to verify the impact of the "January effect" on the instruments on the Stock Exchange in Warsaw. To carry out the study calculated the average monthly returns of companies included in index sWIG80 for the period from January 2007 to December 2015. The calculations were based on daily quotations of selected indices, using a simple rate of return. A study shows that since 2007, the "January effect" has occurred in the stock market, once in 2012. Conclusions from the analysis of the results can be practically applied in making investment decisions.

Keys word: stock anomaly, January effect, behavioral factors

Informacja o autorach:

\section{mgr Berenika Karaszkiewicz}

dr inz. Iwona Staniec

Katedra Zarządzania ,Politechnika Łódzka

ul. Piotrkowska 266, 90-924 Łódź

email: istan@p.lodz.pl 